\title{
Capturing CSR: Doing good offshore
}

\author{
Fay Davidson, John Wreford, Graham Pervan, Kevan Penter \\ School of Information Systems, Curtin University, Western Australia \\ Graham.Pervan@cbs.curtin.edu.au
}

\begin{abstract}
Global monitoring, and other drivers of high level reporting standards, have brought increasing pressure to embed Corporate Social Responsibility (CSR) in the day-to-day operations of many multinational companies. This move toward overt and targeted CSR responses and public reporting is prompting the strategic alignment of CSR with core business. Although driven in part by regulation, CSR initiatives and practice help demonstrate the moral authority of the corporate citizen. Practicing and publicly reporting CSR, presents an organization as ethical and worthy of trust, and in doing so, captures the good will, empathy and trust of stakeholders especially clients, customers and labor, in home countries. The development and maintenance of trust is integral to offshoring success. This research questions how the strategic practice of CSR by organizations, operating global in-house centers (GICs), contributes to relationship management in OBPO by positioning staff in GICs as stakeholders.
\end{abstract}

Key words: OBPO, Corporate Social Responsibility, Captives, Global In-house Centers.

\section{Introduction}

Global monitoring, and other drivers of high level reporting standards, have brought increasing pressure to embed Corporate Social Responsibility (CSR) in the day-to-day operations of many multinational companies. Although driven in part by regulation, CSR initiatives and practice help demonstrate the moral authority of the corporate citizen. Practicing and publicly reporting CSR presents an organization as ethical and worthy of the good will and empathy and in doing so captures stakeholder trust. This move toward overt and targeted CSR responses and public reporting is prompting the strategic alignment of CSR with core business.

The need to capture the approval of customers and stakeholders is crucial to the sustainability of organizations seeking to obtain the efficiencies of offshoring business processes to locations with lower operational inputs. Moving part of an organization's operations offshore can activate fears of job losses in the outsourcing country, perceptions of organizations valuing profit over customer satisfaction, or at the worst, racism and cultural superiority. Convincing clients and customers as stakeholders at home, that offshoring is the best business solution for meeting customer needs, developing business and delivering 
quality and cost benefits all round, requires the development and maintenance of trust in the objectives and motivations of the organization. Kelly and Noonan [1] draw on Giddens'perspective of the changing nature of risk, anxiety, and trust in the context of the contemporary globalization of social relations, and the notion of trust as an emotional commitment. They argue that while risk has been investigated as an element in establishing and maintaining offshoring relationships (for example Willcocks and Lacity [2], and Willcocks et al., [3]) more emotional dimensions have been overlooked, specifically in the courtship and cohabitation phases of the offshoring relationship. According to Kelly and Noonan

"In the Courtship phase, the emphasis was primarily on the client developing trust in the vendor's ability to deliver the system and in the latter's integrity and benevolence toward the former. In the Cohabitation phase, by contrast, the emphasis shifted to a struggle to construct a stable collaborative order, where both parties had to come to mutual accommodations about key social practices".[1]

\section{Research Goal}

Further to this identification of the importance of the emotional element of client and vendor trust, Wreford et al. [4][5] identified the importance of trust as a factor of opaque indifference in end-customer relationships particularly within captive, or global in-house centers (GICs). Similar to Noonan and Kelly's exploration of "anxiety and psychological security; and the role of trust as emotional commitment" [1], this research questions how the strategic practice of CSR by organizations operating global in-house centers contributes to trust and relationship management in Offshore Business Process Outsourcing (OBPO). By positioning staff in GICs, and at home, as stakeholders, the research is proposing a framework for explaining support for CSR implementation, where support means the willingness of organizations to display the implementation of CSR.

\section{Literature Review}

The review begins by examining how CSR is defined by various organizations, and explores the similarities and differences with theoretical arguments defining CSR in the literature.

\subsection{Overview of CSR literature}

The definition of corporate social responsibility can be fluid [6], and difficult to measure. According to Carroll [7], one of the leading researchers in the CSR field, the evolution of the modern era of CSR as a construct began in the1950s expanding during the 1960s and 1970s. "In the 1980s, there were fewer new definitions, more empirical research, and alternative themes began to mature" [7]. 
Like Corporate Governance, CSR has many definitions and connotations: from business ethics or philanthropy or environmental policy, corporate social performance and corporate citizenship [8][9][10] and social accounting or corporate accountability [11]. As Moon argues, "CSR like democracy and justice is an essentially contested concept with it's meaning always debatable" [12] . Wood [13] argues that "CSR, or corporate social performance, can be defined as a business organization's configuration of principles of social responsibility, processes of social responsiveness, and policies, programs, and observable outcomes as they relate to the firm's societal relationships" [13]. This definition, while broad, allows for understanding CSR as a discipline that encompasses frameworks and understandings from many of the social sciences, economics, politics, sociology, environmental science, and business.

Crane et al. [14] argue that "despite the homage to many disciplines, CSR as an academic endeavor fits firmly in the field of business and management" and summarize the existing research as dealing with "broad questions about the changing relationship between business, society and government, environmental issues, corporate governance, the social and ethical dimensions of management, globalization, stakeholder debates, shareholder and consumer activism, changing political systems and values, and the ways in which corporations can respond to new social imperatives" [14]. In a recent review of CSR theories Mele [15] identifies three earlier and important studies, Klonoski [16], Windsor [17] and Garriga and Mele [18]. Klonoski argues that CSR theories take one of three perspectives; fundamentalism, moral personhood and moral agency, or social institutions. Fundamentalism revolves around the value to business of CSR and purely economic analysis. Moral personhood Klonoski argues, is theory that that contends that "...corporations are capable of actions, comparable to the actions taken up by natural persons, those who take this approach to determining CSR argue that corporations can be morally culpable in a way either identical with or very similar to natural persons" [16].

CSR viewed through the social institutions lens can focus on arguments in favor of treating corporations as persons tend either explicitly or implicitly to work from the presumption that business activities occur within an interpersonal if not a social context [16]. There are similarities and differences in the categorizations of Windsor [17] and Klonoski [16]. They both have located an economic theoretical perspective, and a corporate citizen perspective, but Klonoski's moral agency and Windsor's perception of synthesized theories seem to be to blurred and allencompassing and do not successfully categorize modern theoretical analysis of CSR. Mele [15] develops much more workable categories that accommodate more modern theoretical analysis of CSR; corporate social performance, shareholder value theory, stakeholder theory, corporate citizenship. These four categories are more useful for analysis of the interaction between OBPO and CSR because they are closely linked to four areas of decision making in OBPO [15]. By identifying stakeholders and stakeholder positions, this research seeks to grapple with the question posed by Moir [19],

"for those businesses that do undertake what might be termed corporate social 
responsibility, what is actually socially responsible behavior as opposed to management of corporate image management or other activity aimed predominantly at business benefits?"[19].

\subsection{Overview of OBPO research}

The first published review of academic literature on Offshore Business Process Outsourcing examined 87 research articles. The comprehensive review of OBPO completed by Lacity et al. [20] identified papers published between 1996 and 2011 in 67 journals that are described as 'empirically robust BPO articles'. The data used in that research demonstrates that more than half of all the BPO research papers were published in the period 2008-2011, and that most BPO research has been completed and published since 2000. Just over half (58\%) of the published papers have addressed offshore BPO. Lacity et al. [20] identify several themes in OBPO research; BPO decisions, BPO outcomes, and miscellaneous $\mathrm{BPO}$ research themes. It is important to note that none of the $87 \mathrm{BPO}$ papers investigated the interaction or intersection of CSR and OBPO.

Oshri et al. [21] draw our attention to the similarities between early colonial mercantilism and ventures into new world markets for resources and cheap labor, and modern business practices that still source global resources and labor [21]. Oshri and van Uhm [22] provide a detailed history of captive center investments made by Fortune 250 global firms over a period of approximately twenty-five years commencing in 1985 demonstrating that offshore captive centers represent an economic phenomenon of considerable scale and scope. Oshri et al. [21] argue that the primary focus of research dealing with captives is on decisions relating primarily to offshoring and location and that there have been four reasonably distinct phases in the evolution of the of captive centers, and that these phases are marked by the change in the development impetus of decisions to offshore between 1985 and 2010.

- "Phase 1 Moving into India

- Phase 2 Hybrid models

- Phase 3 Expansion of offshore locations

- Phase 4 A drop in captive start-ups, and a pattern of re-shoring or near shoring" [21]

This means that with the progress of time, captives (or global in-house centers) will have their own trajectory of development. Oshri and van Uhm [22] refer to disruptive factors and inhibiting factors as playing a part in developing new models for captive operations [23]. These factors are identified as being improving or worsening economic situations in either the home or offshore country.

Wreford et al. [5] discuss the connections between demonstrating corporate social responsibility and the social license to operate. The social license to operate is an element contributing to consumer support, and balancing the expectations of stakeholders. "It [CSR] is a social contract that reflects the unique 
challenges of this century. As the social and economic landscape continues to shift, business faces a dynamic reality: Legitimacy is never guaranteed, it must be earned every day" [7]. Balancing the expectations of shareholders, complying with applicable laws, managing the implementation of CSR programs, and evaluating the efficacy of CSR goals, are some of the issues confronting companies engaged in OBPO. Some companies recognize that participating in voluntary CSR initiatives can help manage risks, create new business opportunities and improve the prospects for sustainability of the company, while others are concerned with the possible contradiction between the interests of shareholders and the implications of implementing CSR objectives.

\subsection{Gaps in the literature}

Much of the previous research investigating OBPO has focused on the challenges and efficacy of managing offshore relationships [24], developing ways to measure success [25] [20] [26], or critiquing implications for managing personnel and labor metrics [27][28]. Definitions of CSR are generally similar, and usually embrace the notion of corporations responding to an awareness of some social relationship beyond that which is required by law or regulation. However, measuring success, pleasing stakeholders and models of delivery remain contested. Some of the questions central to examining CSR relate to developing new business models incorporating CSR that are palatable to shareholders and other stakeholders. The questions of business practitioners and business scholars alike tend to center on, when is it right for business to become involved in the community, not merely the market? Answers to that question invite analysis from many different fields including politics, business, and economics, and the attendant theories and sub-disciplines. Neither Oshri and van Uhm[22], or Joshi and Mudigonda [23] identify any research about the links between stakeholders and offshoring decisions. This gap in the research means that there has been scant academic investigation of the importance or effect of consumer satisfaction, domestic political responses, or labor relations on organizational decisions to embark in OBPO involving a GICs.

With the strong future for OBPO, as more companies engaged in OBPO reach into the global labor marketplace, and, as CSR develops as a field of research in its own right, understanding the importance between CSR and future decisions about location, model and intensity of OBPO, will rely more than ever before on the ability to answer questions about strategy, stakeholder engagement and impact.

\subsection{Significance of the research and contribution to the field}

As indicated above, no published research has been located that addresses the issues of CSR specifically as an element of the OBPO captive business model. Some of the questions central to examining CSR relate to developing new business models incorporating CSR that are palatable to shareholders and other 
stakeholders. There is evidence in the literature that contracts and well developed business plans alone do not stand as indicators of success [29][30] and that managing the relationships between stakeholders is capturing the attention of academics and offshorers alike. Stakeholders include labor, consumers, legislators and regulators, and shareholders and beneficiaries (in-house centers and vendors) among others. The importance of managing and maintaining these relationships is central to maintaining trust. Lacity and Willcocks [31] point to the strain between competing interests in offshoring relationships; "The provider's centralized culture is looking to generate growth, while the globally dispersed delivery teams want to please both their supervisors and customers, which can leave them caught between conflicting cultures" [31]. St John continues this theme, "Many outsourcing failures are attributed to the failure of relationships, specifically the lack of trust between vendor and client" [29].

It is also well established that the relationship between the vendor and client plays a critical role in the success or failure of the offshore outsourcing arrangement" [29]. CSR plays a role in both creating and ameliorating tensions between stakeholders and competing interests. It contributes to trust, while complicating business imperatives; improves corporate image while intruding on options for efficiencies; appeals to consumers, but disturbs labor, and is both regulated and self-imposed.

The research at hand differs from earlier research in that it seeks to explore a specific area of corporate behavior that is contested and contentious. Global regulations are placing increased expectations on the behavior of offshoring organizations. However, many companies are still evaluating and self-monitoring their corporate social responsibility. The inherent tensions in CSR are the immediate costs and benefits to shareholders and profits, versus, improving the image of the corporate citizen; and the benefits, if any, to the relationships with stakeholders where CSR is being delivered off or onshore. This research examines that intersection of OBPO and CSR as an area of OBPO that has not previously been investigated.

\section{Conceptual Framework and Method}

The first stage of this research is a review of CSR commitments directly linked to global in house centers, as laid out in corporate documents, CSR reports (either in the annual reports, as stand-alone CSR reports where they exist, and/ or sustainability reports, and press releases) for two of the top 200 largest corporations on the Australian Stock Exchange (ASX) companies. This is supported by information gathered through interviews with staff and senior management. This method of examination of organizational CSR commitments has been used widely. The framework frequently follows methodically scoring publications against the economic, social and environmental indicators against core elements of the UN Global Compliance and Global Reporting Initiative (GRI) framework [32]. The Principles of the UN Global compact are distributed under Human Rights and Labor Standards, Environment and Anti-corruption [32] 
McGraw and Dabski, 20102:393 [33] explored the disclosure of CSR by the top 10 Australian companies (based on market capitalization) in 2005. McGraw and Dabski [33] also evaluated 100 annual reports of the ASX top 100. Frost et al. [35] analyzed 25 ASX companies in 2005 against the GRI, and KPMG analyze the reporting of global companies every 2 years, investigating 4100 companies globally in 2013 [34].

Without doubt, evaluating organizational and industry wide responses to CSR by voluntary reporting to GRI frameworks is a common methodology. The growth and persistence in this methodology is important because while there has been ongoing professional and academic debate about the need, value and use of CSR reporting, [1] [36]. A sample of corporate literature produced by some ASX200 organizations is analyzed for details about the cohesiveness of the messages and the extent to which stakeholder audiences are targeted. The overarching messages are isolated and evaluated in terms of their applicability to building trust in brand and consumer approval.

"there is evidence that the number of organizations reporting is increasing rapidly (Brown et al. 2009) despite reluctance on the part of some governments to implement mandatory reporting. $C R$ reporting is now undeniably a mainstream business practice worldwide, undertaken by almost three quarters, (71 percent) of the 4,100 companies surveyed in 2013 [34].

\section{Factors}

\subsection{Utilization of CSR Reporting}

While there is an increase in the number of companies reporting on CSR, the limitation of using annual reports to monitor CSR contributions is noted by Frost et al. [35] as the least valuable source of information. Critics of voluntary CSR reporting argue that voluntary reporting against non-mandatory standards, coupled with organizational management discretion in what is reported, is not conducive to creating equivalencies in comparisons [36]. There is a global trend towards more rigorous regulatory demands on organizations to engage with standards for CSR accounting (for example British Standard BS8900, Denmark Green Accountant Law, Sarbanes-Oxley Act 2002, Nouvelles Regulations Economiques (NRE), ASX Corporate Governance Principles and Recommendations 2010 [37]). As a result, commentators have advocated mandatory reporting (see, for example, Unerman and O'Dwyer [38]), tied much more closely to standards and regulated Jefferey and Pattern [39]. The increase in the numbers of companies reporting appears to indicate that the resistance to report is diminishing. Partly because study after study has shown that corporate social responsibility and sustainability efforts can have demonstrable, positive effects on operations and, ultimately, on bottom line concerns [40]. The links between CSR activities, CSR reporting, and the resulting positive effects on operations 
is central to the analysis of the role of CSR in OBPO. A link between CSR activities and corporate performance appraisals has been clearly visible in the research for some time [41]. The nature of that link is elusive and contestable. This is due to the many elements of CSR and the responsibilities of organizations to various stakeholders.

Schiebel et al. [42] argue that there are six key dimensions of CSR: customers, employees, business partners, the environment, communities and investors [42]. The sometimes competing interests of these 6 stakeholders require tailored management to maximize the benefits of CSR activities and contribute to the benefits and complexities of extending CSR practices to global in house centers by some organizations. McGraw and Dabski [33] identify 5 benefits of CSR practice to companies. They argue that CSR practices have HR benefits because of the "potential to increase employee commitment, make companies more attractive in the labour market and contribute to staff retention." [and] "the positive attributes of CSR are argued to be amplified where CSR activities are strategically aligned with the overall business and will often lead companies to tailor their CSR practices to particular business cultures, social cultures and industries in which they operate as well as moulding them around issues such as risk assessments and license to operate" [33].

Wreford et al. [5] investigated the relationship between CSR and trust in the creation of opaque indifference for end-consumers of OBPO services provided by global-in-house centers, and the management of stakeholder relationships through the lens of moral license. McGraw and Dabski [33] also argue that there are positive links between stakeholders and organizations that acknowledge the impact of their activities on the community and environment. There is considerable investigation of the impact of perceived CSR activities of organizations on stakeholder behavior. There is also evidence that end-customers will change their consumer behavior to support brands and companies considered to have good reputations in CSR (e.g., Brown and Dacin [43]; Sen and Bhattacharya [47] Oberseder [48][49], Becker-Olsen et al. [50]), and that CSR reporting can be used to advantage after periods of strained public relations or in response to negative social perceptions [48].

\subsection{CSR reporting and staff as stakeholders}

Sen and Bhattacharya [51] investigated the types of CSR that organizations can undertake and the impact on various consumer segments. CSR appears to be a useful tool for not only managing brand image and customer loyalty, but also for improving employee commitment. Increasingly, it appears that there are internal advantages in reporting CSR. According to a Centre for Australian Ethical Research (CAER)

"the main target audiences for sustainability reports are employees (87 per cent), customers (79 per cent), shareholders (74 per cent), local community (67 per cent), institutional investors (54 per cent), suppliers (59 per cent), analysts (51 per cent), and governments and NGOs (28 per cent)" [52]. 
An internal focus and use of CSR reporting of activities, is particularly relevant to organizations involved in OBPO and the management of global-in-house centers. Firms view CSR practices as critical to employee morale, recruitment, retention and productivity [53]. Kim et al. investigated marketing CSR performance for the purposes of human resource management and found that

"CSR initiatives enhance the performance of sales staff (Larson et al., 2008), employees' commitment to the organization (Brammer et al., 2007; Peterson, 2004a; Rupp et al., 2006), and their identification with the company (Berger et al., 2006; Collier and Esteban, 200\%; Rodrigo and Arenas, 2008)" [54].

The growth in global in house centers and OBPO presents a new element of competition in the global talent pool. Clive Wincup, CIO of Westpac claimed that it was lack of available skills, not labor costs that drove organizations to engage in a global supply chain of IT professionals.

"... the lack of availability of skills means engaging in a global supply chain of IT professionals. Companies offshore IT jobs due to cost is a fallacy, as salary gaps between countries like India and Australia are closing at a rapid rate" [53]. Although this statement sparked a volley of arguments from commentators and industry observers, there is little doubt that this expansion into global supply chains of IT professionals brings with it new demands on human resource talent management. These new demands relate to the need for labor management to operate in cross cultural workplace environments on an increasingly complex and demanding scale [57] [58]. This is particularly played out at management levels, where there is a need for managers who have social cognitive and political capital [59]. The importance of offshore senior management, is in itself, a link to the legitimacy and ability of the organization to negotiate the offshore commercial environment. ". . a continuous reliance on home country nationals to staff the upper echelon of management team may damage the legitimacy of the MNE in the host country ... without which they would not be able to access valuable resources that are vital for their survival capability" [60].

Bhattacharya et al. [61] argue, CSR is a lever to attract and retain staff by the organization acting as an enabler for individuals to take ownership of CSR. "For example, in a bid to burnish their images as socially responsible companies and thereby attract and retain talent, CEOs of high-profile companies such as Home Depot, Delta Air Lines and SAP recently pledged to deploy millions of employee volunteers to work on various community projects" [60]. These include encouraging staff to work as volunteer days, actively pursing gender equity and diversity in staffing, and promoting their commitment to work-life balance, along with various contributions to charity and concessions to the environment. CSR activity and demonstration in GICs is important to the retention and attraction of staff, especially higher level staff, but that the commitment to CSR is moderated by variables based in the home country.

Drawn from the literature, the research at hand finds that there are then 4 variables that impact on the CSR image of an organization: 
- Demonstrated commitment to CSR in parent organization (e.g. alignment with internal values, specialized units, and investment value),

- Public dissemination of CSR activities - or how CSR is utilized by the organization (e.g. marketing, to groom future consumers, to nurture mutually beneficial relationships),

- the style/type of consumer, and

- the Relationship with labor (or organized labor)

Public dissemination of CSR activities can occur in the broadest and most overt arenas such as supporting staff to take up volunteer work, funding charity initiatives, or implementing safe working or CSR caveats throughout the supply chain. The willingness to publicize CSR initiatives is not universally embraced by all industry sectors. "Observers, critics and academics notice that the fashion and service industries tend to not draw consumer attention to CSR" [56]. This distinction should not be confused with Matten and Moon [62] 's "implicit and "explicit CSR, but understood more in terms of drawing attention of consumers. Robinson et al argue that some fashion and sporting goods manufacturers only mention CSR in shareholder communications [56]. In Banking and Finance and Natural Resource sectors, CSR activities are widely publicized in commercials and promoting brands.

\subsection{Commitment}

One of Australia's 'Big Four' banks, ANZ, has a corporate responsibility framework. In 2011, ANZ reported nine independent audits of major suppliers to ensure they had abided by its responsible sourcing code of practice. Toby Kent, ANZ's head of corporate responsibility (CR), observed that in some organizations " $C R$ is just $P R$. Yet there are many organizations which are moving to act in more sustainable ways, Kent says. Those doing it best are companies that closely tie their corporate responsibility activities to the core business" [63]. The ANZ Bank, Westpac, National Australia Bank and Telstra all have large CSR initiatives. Westpac was ranked the world's most sustainable company, and ANZ was ranked 19 at the World Economic Forum in Davos 2014 Commitment to CSR is critically linked to CSR leadership and champions within the organization. In examining the views of leaders in some large financial organizations, Lindorff and Peck [64] concluded that while employees may influence CSR outcomes, leaders support the wealth creation model's central premise that the organization's primary responsibility is to maximize its value in order to meet its fiduciary obligations to its shareholders, they also believe that CSR activities benefit the organization financially and in building corporate sustainability, employee engagement and performance, and social capital. CSR activities are also believed to increase the legitimacy of the organization, although philanthropy is not supported unless there is a business case. This indicates that commitment can be tempered or scaled according to the drive of leadership and the temperament of shareholders and staff. 


\subsection{Style/type of consumer}

A 2008 study revealed that over $30 \%$ of the media releases of Australia's 'Big 4' banks discussed CSR and that the discussion of CSR was large addressed to consumers and the community [65]. The Australian banking system can have most demanding clients. Measuring the alignment between stakeholder CSR expectations of values and policies, and the company CSR disclosed commitment is important, and there have been some studies evaluating national responses of consumers and stakeholders [66] [67]. Calabrese et al. [68] propose a 9 point matrix based on a scale that likens the customer company relationship to the stages of a domicile relationship. Sen and Bhattacharya [51] investigated the influence of CSR and consumer intentions and concluded that, under certain conditions, consumer reaction may be less positive than anticipated. Weaknesses have been found to exist in the high correlation of CSR and consumer intention depending on market segment and type of consumer.

\subsection{Relationship with labor}

The ANZ, Westpac, NAB and Telstra and other multi-nationals have been subject to negative portrayals in the media of shifting jobs offshore to areas of cheaper labor. The number of jobs going offshore is picking up pace with the financial services industries looking for ways to cut costs by outsourcing back office operations to India. Headlines screamed "Westpac to send 83 jobs to India in cost-cutting program" [69] "ANZ cuts jobs as roles sent offshore" [70] are typical of newspaper headlines. These headlines are often accompanied by responses and sound bites from Union officials, and customer and worker anxiety whipped up by talk back radio. The debate often centers on the accent of call center employees and the low cost of labor. Resistance to offshoring is most visible the public arena when it is played out in the industrial relations field. "Union outrage as Telstra sends 170 jobs to India" [71]. "Union Anger As Jobs Go Offshore" [72][73].

CSR reporting can be a tool for repairing damaged community relationships.The ANZ self reports,

"In India for example, we employed 15 people with a self disclosed disability in 2012 and a further 18 have been recruited over the last six months" [74].

As ANZ expanded its regional growth ambitions that now span 26 countries in the Asia Pacific Region, it took the decision in 2004 to strengthen and expand the role of its captive operation and, under the slogan 'ANZ in Bangalore', develop an integrated captive that was fully assimilated into the parent company. Staff members in Bangalore were given the same corporate and organizational training as staff in the parent company, and $\mathrm{HR}$ and corporate policies and controls were the same as in other parts of the ANZ bank [75]. The Managing Director summarized the culture of ANZ's Bangalore captive center:

"We revere the culture here [in Bangalore] but we remember who we are. We are not here as apologists. We make sure that all staff know about our standards and our values". ANZ was selective in the business processes transferred offshore, 
with a former CEO noting that "ANZ understands customers want to be able to talk to staff in Australia about their banking and financial services needs. As a result, we have a clear policy that all call centers for Australian customers will remain in Australia" [75].

This appears to be an example of the end customers as a major stakeholder in the organizational field exerting a coercive influence over the choice of business processes to be performed in the offshore captive center.

\section{Model}

Web resources and materials directed at recruiting offshore seem to support the 'one organization' style agenda.

"ANZ supports an inclusive workplace where employee differences, such as gender, age, culture, disability and lifestyle choice are valued."

"ANZ strives to build a high performance values-driven culture where our people make decisions in the best interests of our stakeholders." [76]

"Our Vision for Telstra as a Place to Work

Through our leadership actions and behaviors, our environment and culture, we'll inspire our people to create meaningful interactions with our customers. We'll achieve this by putting our people first and respecting each other's unique talents, gifts and capabilities. We believe that if we care deeply about our people, they will pass on the love to our customers!" [77].

These overt assertions signal recognition of the importance of including staff as stakeholders as recipients and participants of CSR, and awareness of the role of the organization in the social constructs and relationships within the community and with end customers.

The four factors identified impact on the commitment to CSR in GICs. Telstra ANZ and Westpac all seek to produce recruitment materials for staff working off shore that rounds off their commitment to staff and draws attention to supportive workplace cultures. The ANZ reports that the female Managing Director of ANZ's Bangalore operation hub who leads almost 600 people says "I've found that to be successful in banking, you really need to be interested in people and care about what they want for their careers and lives" [78].

\section{Limitations of this Research}

A limitation on the capacity to generalize from this research is that it is focused on client (i.e. outsourcing) companies that operate primarily from Australia and United Kingdom, with either captive operations or BPO service providers primarily located in India and the Philippines. Deeper investigation of other forms 


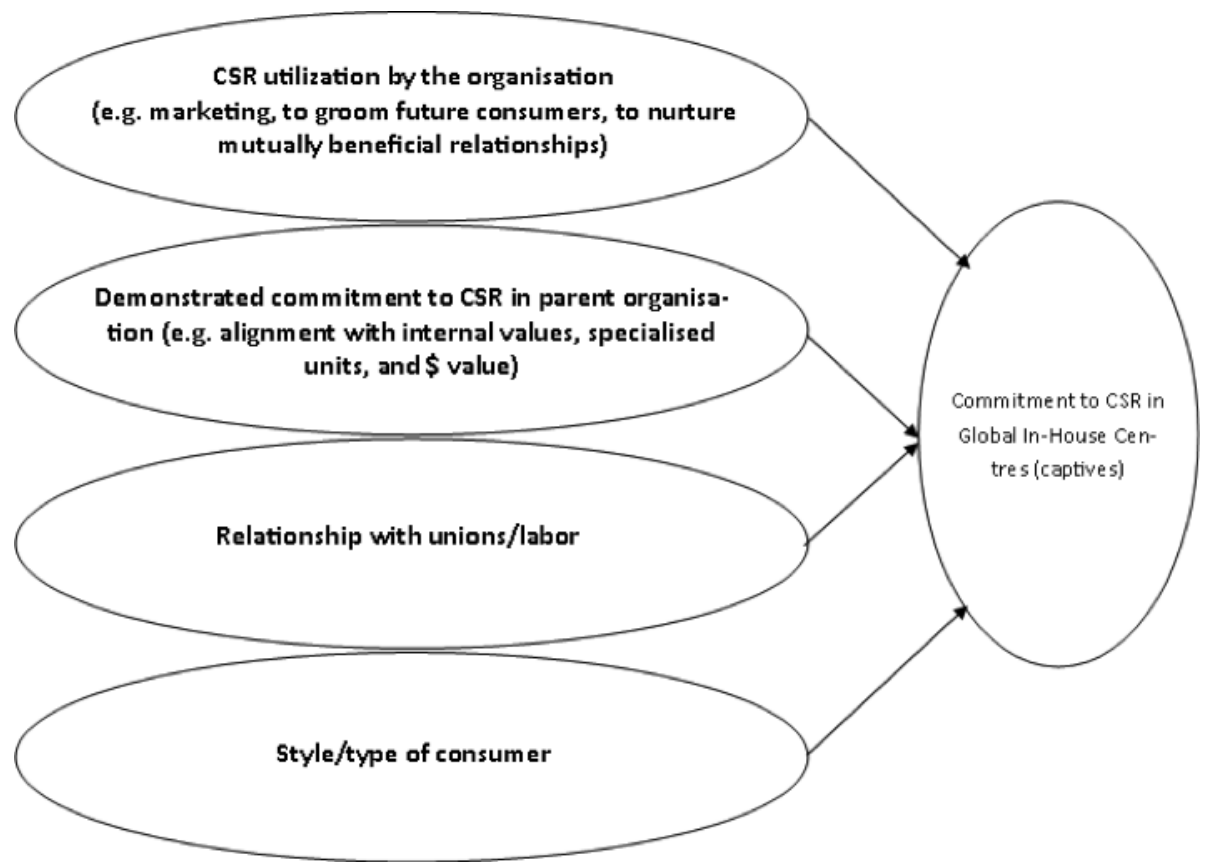

Fig. 1. Commitment to CSR in GIC

of CSR practices in captive organizations would lead to a richer understanding of the value of CSR to offshoring organizations.

\section{Conclusions}

The factors or variables (in the model Figure 1.) contribute to support for CSR implementation in captive GICs. Support, in this model means, the depth/strength or organizational commitment, to willingness to implement and style of CSR implemented in the captive. Utilizing CSR as a management tool to assist in attracting and retaining staff in GICs may provide leverage in containing and possibly reducing high rates of staff turnover (sometimes referred to as staff attrition or churn). Reducing staff turnover lowers operating costs associated with recruitment, induction, training and enhances the effectiveness of knowledge transfer, thus contributing to successful outcomes. There is room within each of the four variables for scaled differentiation of the performance of individual organizations and their behavior or relationships with the relevant area. Where the behavior and expectations of all groups within all variables are high, it is reasonable to expect that the commitment and exercise of CSR would extend fully to the CSR demonstrated in the GIC. For example, in ANZ Bangalore information for new staff includes this statement of commitment, " $A N Z$ Bangalore is committed to earning the trust of the community we live and work 
in. We have an agenda that aims to make a significant positive impact on our community and fulfill our social responsibilities" [79].

\section{Future Research}

Captive OBPO centers as is an area of research still in its infancy. Investigation of the depth and breadth of the types and style of CSR practiced by organizations, particularly those operating in languages other than English would enrich the knowledge base. It is our (tentative) hypothesis that the commitment to practicing CSR within the captive is proportional to the importance of CSR to end customers. The questions for further research are: Is there any difference in the strength of each variable that contributes to the types of CSR exercised in captives? And how important is CSR in OBPO success? Matten and Moon [62] remind us that defining CSR is not just a technical exercise but also a normative and ideological exercise that varies across nations. So simple evaluations of CSR copied from home country to host must be cognizant of how moral understandings and cultural understandings translate across shores. Future research might consider if there should be any difference in the types, expectations, or delivery of CSR values and programs in captive organizations. -

\section{References}

1. Kelly, S., Noonan, C.: Anxiety and psychological security in offshoring relationships: the role and development of trust as emotional commitment. Journal of Information Technology, 23, 232-248 (2008)

2. Willcocks, L.P., Lacity, M.: IT outsourcing in insurance services: risk, creative contracting and business advantage. Information Systems Journal 9,163180 (1999)

3. Willcocks, L.P., Lacity, M., Kern, T.: Risk mitigation in IT outsourcing strategy revisited: Longitudinal case research at LISA. Journal of Strategic Information Systems 8, 285-314 (1999)

4. Wreford, J., Penter, K., Pervan, G., Davidson, F.: Seeking opaque indifference in offshore BPO, In: Kotlarsky, J., Oshri, I., Willcocks, L.P. (eds.) The Dynamics of Global Sourcing: Perspectives and Practices Lecture Notes in Business Information Processing, 130,175-193, Verlag ,Heidelberg (2012)

5. Wreford, J., Davidson, F., Pervan, G. Penter, K., Opaque indifference and corporate social responsibility: A moral license for offshore BPO. In: Oshri, I., Kotlarsky, J., Willcocks, L.P. (eds.) Advances in Global Sourcing: Models, Governance, and Relationships Lecture Notes in Business Information Processing, 163,192-209, Verlag ,Heidelberg (2013)

6. Thomas, G., Nowak, M.: Corporate Social Responsibility: a definition. Working paper series no. 62 , Graduate School of Business, Curtin University of Technology, Perth, Western Australia. (2006) 
7. Carroll, A.B.: Corporate social responsibility: evolution of a definitional construct. Business and Society 38, 268-295 (2012).

8. McWilliams, A., Siegel, D.: Corporate social responsibility: strategic implications. Journal of Management Studies 43, 1-18 (2006)

9. Secchi, D.: Utilitarian, managerial and relational theories of corporate social responsibility. International Journal of Management Reviews 9, 347-373 (2007)

10. Windsor, D.: Corporate social responsibility: three key approaches. Journal of Management Studies 43, 93-114 (2006)

11. Aras, G., Crowther, D.: Corporate sustainability reporting: a study in disingenuity?. Journal of Business Ethics 87, 279-288. (2009)

12. Moon, J.: Corporate social responsibility: an overview. In: Hartley, C. (ed.) The International directory of corporate philanthropy, 3-14. Europa Publications, New York (2002)

13. Orlitzky, M., Frank L. Schmidt, S., Rynes, L., Corporate social and financial performance: a meta-analysis. organization studies 24, 403-441 (2003)

14. Crane, A., McWilliams, A., Matten, D., Moon, J., Siegel, D.S.: The Oxford handbook of corporate social responsibility, Oxford University Press, Oxford (2008)

15. Mele, D.: Corporate social responsibility theories. The Oxford handbook of corporate social responsibility, 48-82 (2008)

16. Klonoski, R.J.: Foundational considerations in the corporate social responsibility debate. Business Horizons 34, 9-18 (1991)

17. Windsor, D.: Corporate social responsibility: three key approaches. The Journal of Management Studies 43, 93-114 (2006)

18. Garriga, E., Mele, D.: Corporate social responsibility theories: mapping the territory. Journal of Business Ethics 53, 51-71 (2004).

19. Moir, L. What do we mean by corporate social responsibility?. Corporate Governance 1,16 - 22 (2001)

20. Lacity, M., Khan, S., Yan, A., Willcocks, L.: A review of the IT outsourcing empirical literature and future research directions. Journal of Information Technology 25, 395-433 (2010)

21. Oshri, I., Julia Kotlarsky., Willcocks, L.P.: The handbook of global outsourcing and offshoring. Palgrave Macmillan, United Kingdom (2011)

22. Oshri, I., van Uhm, B.: A historical review of the information technology and business process captive center sector. Journal of Information Technology $27,270-284(2012)$

23. Joshi, K., Mudigonda, S.: An analysis of India's future attractiveness as an offshore destination for IT and IT-enabled services. Journal of Information Technology 23, 215-227 (2008)

24. Cullen, S., Seddon, P.B., Willcocks, L.P.: Managing outsourcing: the life cycle imperative. MIS Quarterly Executive 4, 357-387 (2005)

25. Aubert, B., Rivard, S., Patry, M.: A transaction cost model of IT outsourcing. Information and Management 41, 921-932 (2004) 
26. Lee, J-N., Miranda,S.M., Kim, Y-M.: IT outsourcing strategies: Universalistic, contingency and configurational explanations of success. Information Systems Research 15, 29-61 (2004)

27. Capron, L., Mitchell, W.: Selection capability: how capability gaps and internal social frictions affect internal and external strategic renewal. Organization Science 20, 294-312 (2009)

28. Ho, L., Atkins, A.S.: Performance measurement in an outsourcing environment. In: Shi, N.S., Silvius, G.,(eds.) Enterprise IT Governance, Business Value and Performance Measurement, 220-230. Information Science Reference, New York (2011)

29. St. John, J., Guynes, C.S.: Vedder, R.: The value of partnership in offshoring. Journal of Business and Economics Research 11, 297-300 (2013)

30. Willcocks, L., Choi, C. J.: Co-operative partnership and total IT outsourcing: from contractual obligation to strategic alliance?. European Management Journal 13, 67-78 (1995)

31. Lacity, M.C., Willcocks, L.P.: Outsourcing business processes for innovation, MIT Sloan Management Review 54, 63-69 (2013)

32. UN Global Reporting Initiative, https://www.globalreporting.org (2014)

33. McGraw, P., Dabski, S.:Corporate social responsibility reporting in Australia's largest companies., Labour and Industry 21, 390-409 (2010)

34. KPMG: The KPMG survey of corporate responsibility reporting. (2013)

35. Frost, G., Jones. S, Loftus, J., Van Der Laan, S.: Sustainability reporting: a survey of sustainability reporting practices of Australian reporting entities. Australian Accounting Review 15, 89-96 (2005)

36. Halabi, A.K., Kazi, A.U., Dang, V., Samy, M.: Corporate social responsibility: how the top ten stack up, Monash Business Review 3, 20-24 (2006)

37. ASX Corporate governance council,: Corporate governance principles and recommendations 3rd Edition. ASX Corporate Governance Council, Australia (2014)

38. Unerman, J. O'Dwyer, B.: The business case for regulation of corporate social responsibility and accountability. Accounting Forum 31, 332-353 (2007)

39. Jeffrey, C., Perkins, J. D.: Developing corporate reporting in the public interest: the question of mandatory CSR reporting and the potential for its integration with financial reporting. Accounting for the Public Interest 177-200 (2014)

40. Brown, J., Fraser, M.: Approaches and perspectives in social and environmental accounting: an overview of the conceptual landscape. Business Strategy and the Environment, 15, 103-117 (2006)

41. Lockwood, N. R., Corporate social responsibility: HR's leadership role. International Society for Performance Improvement Research Quarterly. (2013)

42. Schiebel, W., Pchtrager, S.: Corporate ethics as a factor for success?the measurement instrument of the University of Agricultural Sciences (BOKU), Vienna. Supply Chain Management: An International Journal 8, 116-121 (2003) 
43. Brown, T. J., Dacin, P. A.: The company and the product: corporate associations and consumer product responses. The Journal of Marketing, 68-84 (1997).

44. Bhattacharya, C. B., Sen, S.: Doing better at doing good: When, why, and how consumers respond to corporate social initiatives. California Management Review 47, 9-24 (2001)

48. Oberseder, M., Schlegelmilch, B. B., Gruber, V.: Why don't consumers care about CSR?: a qualitative study exploring the role of CSR in consumption decisions. Journal of Business Ethics 104, 449-460 (2011)

49. Oberseder, M., Schlegelmilch, B. B., Murphy, P. E.: CSR practices and consumer perceptions. Journal of Business Research 66, 1839-1851 (2013)

50. Becker-Olsen, K. L., Cudmore, B. A., Hill, R. P.: The impact of perceived corporate social responsibility on consumer behavior. Journal of Business Research 59, 46-53 (2006)

51. Sen, S. and Bhattacharya, C.B.: Does doing good always lead to doing better? Consumer reactions to corporate social responsibility. Journal of Marketing Research 38: 225-243 (2001)

52. Australian Parliament House Parliamentary Joint Committee on Corporations and Financial Services.: Corporate social responsibility and financial performance in the Australian context, Corporate responsibility: Managing risk and creating value. Commonwealth of Australia, Canberra (2006)

53. Maltese, R.: CSR's limited presence in narrative data suggests untapped opportunity in CSR report 2013, In: De Leo, F., Quinn, F. (eds)., Innovatio Publishing Ltd. Beirut (2013)

54. Kim, H. R., Lee, M., Lee, H. T., Kim, N. M.: Corporate social responsibility and employee company identification. Journal of Business Ethics 95, 557-569 (2010)

55. Lui, S.: Offshoring myths perpetuating IT skills shortage: Westpac CIO. http://www.zdnet.com/au/offshoring-myths-perpetuating-it-skills-shortage-westpaccio-7000005432/ (2012)

56. Robinson, I., Meyer, R., Kimeldorf, H.: The strength of weak commitments: market contexts and ethical consumption. In: Bair, J., Miller, D., Dickson, M., (eds.) Workers' rights and labor compliance in global supply chains: is a social label the answer. Routledge, New York (2014)

57. Mehta, A., Armenakis, A., Mehta, N., Irani, F.: Challenges and opportunities of business process outsourcing in India. Journal of Labor Research 27, 323-338 (2006)

58. Aubert, B. A., Rivard, S., Templier, M., Information technology and distance-Induced effort to manage offshore activities. IEEE Transactions on Engineering Management 99, 1-14 (2011)

59. Ang, S., Inkpen. A.C.: Cultural Intelligence and Offshore Outsourcing Success: A Framework of Firm-Level Intercultural Capability. Decision Sciences 39, 337-358 (2008) 
60. Farndale, E., Sucllion, H., Sparrow., P.: The role of the corporate HR Function in global talent management. Journal of World Business 45, 161-168 (2010)

61. Bhattacharya, C. B., Sen, S., Korschun, D.: Using corporate social responsibility to win the war for talent. MIT Sloan Management Review 49, 37-44 (2008)

62. Matten, D., Moon, J.: Implicit and explicit CSR: A conceptual framework for a comparative understanding of corporate social responsibility. Academy of Management Review 33, 404-424 (2008)

63. Australian School of Business: Corporate Social Responsibility: A Fig Leaf for Capitalism or Path to a Better World?: http://knowledge.asb.unsw.edu.http://knowledge.asb.unsw.e (2012)

64 Lindorff, M., Peck, J.: Exploring Australian financial leaders' views of corporate social responsibility. Journal of Management and Organization 16, 48-65 (2010)

65. Reinig, C. J., Tilt, C.A., Corporate social responsibility issues in media releases: A stakeholder analysis of Australian banks. Issues in Social and Environmental Accounting 2, 176-197 (2008)

66. Maddern, H., Maull, R., Smart, A., Baker, P.: Customer satisfaction and service quality in UK financial services. International Journal of Operations and Production Management 27, 998-1019 (2007)

67. Visser,W., Tolhurst, N. (eds.).:The world guide to CSR; A country by country analysis of corporate responsibility and sustainability. Greenleaf Publishing, United Kingdom (2010)

Maddern, H., Maull, R., Smart, A., Baker, P.: Customer satisfaction and service quality in UK financial services, International Journal of Operations and Production Management 27, 998-1019 (2007).

68. Calabrese, A., Costa, R., Menichini, T., Rosati, F.: Measuring the CSR company-stakeholder fit. World Academy of Science, Engineering and Technology International Journal of Social, Management, Economics and Business Engineering $6,(2012)$

69. Bennet, M.: Westpac to send 83 jobs to India in cost-cutting program. The Australian, October 18, (2013)

70. ANZ cuts jobs as roles sent offshore. The Australian, February 20, (2013)

71. Bingemann, M.: Union outrage as Telstra sends 170 jobs to India. The Australian, July 10 (2013)

72. Lucas, C.: Union anger as jobs go offshore, Sydney Morning Herald, March1, (2013)

73. Durvasulaa, S., Lysonski, S.: How offshore Outsourcing is Perceived: Why Do Some Consumers Feel More Threatened?. Journal of International Consumer Marketing 21, (2008)

74. ANZ Corporate Responsibility Report Interim Report 2012, Sydney Australia. http://www.anz.com.au/india/en/about\%2Dus/corporate\%2Dresponsibility/in\%2Dindia/ (2012) 
75. Penter, K., Wreford, J., Pervan, G., Davidson, F.: Offshore BPO decisions and institutional influence on senior managers. In: Advances in Global Sourcing. Models, Governance, and Relationships, 93-116 Springer Berlin Heidelberg (2013)

76. ANZ in India. http://www.anz.com.au/india/en/about-us/careers/whowe-are/

77. Telstra. http://philippines.careers.telstra.com/a-great-place-to-work

78. ANZ (2012) Corporate responsibility report interim report 2012, Sydney Australia. http://www.anz.com.au/india/en/about\%2Dus/corporate\%2Dresponsibility/in\%2Dindia/ 79. http://www.anz.com.au/india/en/About\%2DUs/Corporate\%2DResponsibility/In\%2DIndia/ 